A comparative study of iron and temperature interactive effects on diatoms and Phaeocystis antarctica from the Ross Sea, Antarctica

Zhi Zhu

Kai Xu

Feixue Fu

Jenna L. Spackeen

Deborah A. Bronk

See next page for additional authors

Follow this and additional works at: https://scholarworks.wm.edu/vimsarticles

Part of the Oceanography Commons 
Authors

Zhi Zhu, Kai Xu, Feixue Fu, Jenna L. Spackeen, Deborah A. Bronk, and David A. Hutchins 


\title{
A comparative study of iron and temperature interactive effects on diatoms and Phaeocystis antarctica from the Ross Sea, Antarctica
}

\author{
Zhi Zhu ${ }^{1, *}$, Kai Xu ${ }^{1, *}$, Feixue Fu' ${ }^{1}$, Jenna L. Spackeen ${ }^{2}$, Deborah A. Bronk ${ }^{2}$, \\ David A. Hutchins ${ }^{1, * *}$ \\ ${ }^{1}$ Department of Biological Science, University of Southern California, Los Angeles, CA 90089, USA \\ ${ }^{2}$ Department of Physical Sciences, Virginia Institute of Marine Science, College of William \& Mary, PO Box 1346, \\ Gloucester Point, VA 23062, USA
}

\begin{abstract}
In the future, temperature and iron availability are predicted to change in the coastal polynyas of Antarctica, which are the most biologically productive regions of the Southern Ocean. We examined the individual and combined effects of iron addition $(+500 \mathrm{nM})$ and temperature increase $\left(4^{\circ} \mathrm{C}\right)$ on Phaeocystis antarctica and several dominant diatom species isolated from the McMurdo Sound sector of the Ross Sea. Iron addition increased growth, carbon fixation, iron uptake rates, cellular carbon quota, and cell size of almost all tested species, while temperature increase only affected certain species. Concurrent increases in temperature and iron synergistically stimulated the growth rates of some species, particularly Pseudo-nitzschia subcurvata. The diversified responses of these phytoplankton to iron and temperature may help explain the current spatial and temporal distributions of diatoms and prymnesiophytes in the Ross Sea. In the future, potential temperature and iron increases may promote the growth of the diatoms Chaetoceros sp., Fragilariopsis cylindrus, and especially $P$. subcurvata. In contrast, growth rates of $P$. antarctica did not increase at higher temperatures, suggesting that a shift in community composition toward diatoms may occur under warmer conditions in this biologically and biogeochemically important Southern Ocean polynya region.
\end{abstract}

KEY WORDS: Antarctic - Global warming - Fe input · Phytoplankton community - Diatom · Phaeocystis $\cdot$ Pseudo-nitzschia

\section{INTRODUCTION}

The annual austral spring and summer algal blooms in the Ross Sea, Antarctica contribute as much as $28 \%$ of the total oceanic primary production in the Southern Ocean (Arrigo et al. 1998). These primary producers support a thriving food web, and make this polynya one of the most biologically productive areas in the Southern Ocean (Arrigo et al. 1999, 2008b, Smith et al. 2000). Carbon fixation and export by these algal blooms also make the coastal Southern Ocean an important $\mathrm{CO}_{2}$ sink (Arrigo et al. 2008a).
The colonial prymnesiophyte Phaeocystis antarctica and multiple species of diatoms are the 2 dominant phytoplankton taxa in the Ross Sea (DiTullio \& Smith 1996, Arrigo et al. 1999, 2000). Diatom assemblages are usually composed of Pseudo-nitzschia subcurvata, Fragilariopsis spp., Thalassiosira spp., and Chaetoceros spp., as well as various other species (Leventer \& Dunbar 1996, Arrigo et al. 1999, Goffart et al. 2000, Rose et al. 2009). P. antarctica typically initiates the bloom in austral spring when the mixed layer is deep, and continues to dominate until mid-summer, especially in the southeast polynya of the Ross Sea (DiTullio \& Smith 1996, Arrigo et al. 
1999). In contrast, diatoms normally bloom after $P$. antarctica during the late austral summer, and are particularly dominant in the northwest Ross Sea along the coast of Victoria Land and in Terra Nova Bay (DiTullio \& Smith 1996, Arrigo et al. 1999). Mixed layer depth and water column temperature have been suggested as the main factors that determine the spatial and temporal distributions of $P$. antarctica and diatoms in the Ross Sea (Arrigo et al. 1999, Liu \& Smith 2012).

In addition to being important contributors to the global carbon cycle and anthropogenic $\mathrm{CO}_{2}$ drawdown, $P$. antarctica plays a large role in global sulfur biogeochemistry, and diatoms have a major influence on the global silicon cycle (Tréguer et al. 1995, Arrigo et al. 1999, Schoemann et al. 2005). P. antarctica has higher N:P and C:P ratios, so it can export more $\mathrm{N}$ and $\mathrm{C}$ per mol of $\mathrm{PO}_{4}{ }^{3-}$ removed relative to diatoms (Arrigo et al. 1999, 2000). The colonial morphology of $P$. antarctica may deter grazing by microzooplankton (Caron et al. 2000), and diatoms are important in supporting the krill-based food webs of the Southern Ocean (Knox 1994). Thus, any shift in Ross Sea phytoplankton community structure has the potential to affect the global biogeochemical cycles of carbon, sulfur, silicon, and other major nutrients (Arrigo et al. 1999, DiTullio et al. 2000).

The Southern Ocean is predicted to experience significant warming caused by increasing atmospheric $\mathrm{CO}_{2}$ (Manabe \& Stouffer 1993, Sarmiento et al. 1998), and the West Antarctic Peninsula (WAP) has been notable as one of the most rapidly warming areas on the planet (Vaughan et al. 2003). Decreased ice cover and increased stratification caused by ongoing climate change has already influenced the marine biological community along the WAP (Montes-Hugo et al. 2009). In contrast, the Ross Sea has experienced cooling and increases in sea ice duration and extent in recent years (Comiso et al. 2011, Smith et al. 2012, Stammerjohn et al. 2012). Nevertheless, given current climate trends, the Ross Sea is also expected to experience significant warming and loss of sea ice by the end of this century (Ainley et al. 2010). The intensified stratification caused by this projected warming may profoundly influence the nutrient upwelling, mixed layer depth, and light regime of the Ross Sea (Boyd \& Doney 2002, Montes-Hugo et al. 2009).

Iron $(\mathrm{Fe})$ has been conclusively proven to be the primary limiting nutrient for the high-nutrient, lowchlorophyll (HNLC) regime in the Southern Ocean. Many experiments have shown that Fe addition stimulates the growth of phytoplankton, especially the proliferation of diatoms (de Baar et al. 1990, Martin et al. 1990, Takeda 1998, Boyd et al. 2000, Sedwick et al. 2000, Hutchins et al. 2002, Coale et al. 2004). Aeolian deposition, deep water upwelling, and sea ice melting are the major Fe input pathways into the Southern Ocean (Sedwick \& DiTullio 1997, Elrod et al. 2004, Jickells et al. 2005), however, the effects of global change on these Fe inputs are currently unresolved. For instance, predictions from 2 models show very different trends in global dust fluxes (ranging from a $60 \%$ decrease to a $12 \%$ increase) in the next 100 yr (Mahowald \& Luo 2003, Tegen et al. 2004). Local dust inputs could also become a significant source of iron to the coastal Southern Ocean, due to reduced terrestrial ice and snow cover as a result of a warming climate (Cook et al. 2005, Overpeck et al. 2006, Raiswell et al. 2006). Melting of glacial ice and icebergs may increase future Fe inputs into the Antarctic coastal ocean (Overpeck et al. 2006, Raiswell et al. 2006, 2008). Changes to stratification and upwelling in the future may also impact Fe concentrations in the upper water column. Fe inputs from upwelling may decrease with increased stratification, and thus intensify Fe limitation of the HNLC region (Boyd \& Doney 2002, Montes-Hugo et al. 2009); alternately, Fe inputs from upwelling may increase due to increased wind speeds in a warmer climate (Anderson et al. 2009). Although it is currently challenging to predict the net trends in Fe inputs to the Ross Sea, it seems quite likely that both future Fe availability and sea surface temperature may deviate substantially from current conditions.

The biological consequences of potential interactions between Fe supply changes and temperature increases are poorly understood. In a shipboard experiment, Rose et al. (2009) found that Fe addition and temperature increase synergistically promoted the growth of a natural phytoplankton community obtained from the Ross Sea, with diatoms dominating the final assemblages rather than $P$. antarctica. Xu et al. (2014) examined the effects of 'clustered' global change factors including warming, light, ocean acidification, and Fe availability on P. antarctica and the diatom Fragilariopsis cylindrus. Their results suggested that diatoms may outcompete $P$. antarctica under a combined suite of simulated future conditions.

Research on the interactive effects of temperature and $\mathrm{Fe}$ on representative individual phytoplankton species from Ross Sea is scarce; therefore, this study aimed to explore the effects of temperature increase and Fe addition on P. antarctica and several ecologically important diatom species. The results are intended to help us predict the potential effects of global change on the phytoplankton community, 
food webs, and biogeochemical cycles of carbon, Fe, and nutrients in the coastal polynyas of Antarctica.

\section{MATERIALS AND METHODS}

\section{Strains and growth conditions}

Unialgal cultures of Pseudo-nitzschia subcurvata, Chaetoceros sp., Fragilariopsis cylindrus, and Phaeocystis antarctica were isolated from the ice edge in McMurdo Sound $\left(77.62^{\circ} \mathrm{S}, 165.47^{\circ} \mathrm{E}\right)$ in the Ross Sea, Antarctica during January and February 2013. $P$. antarctica grew in the non-colonial form, as single flagellated cells. All stock cultures were maintained in $0.2 \mu \mathrm{M}$-filtered seawater that was collected using trace metal clean techniques from the same locale as the culture isolates (Hare et al. 2007, King et al. 2012). Cultures were grown at $0^{\circ} \mathrm{C}$ in a walk-in incubator under $24 \mathrm{~h}$ cold white fluorescence light (80 $\mu$ mol photons $\mathrm{m}^{-2} \mathrm{~s}^{-1}$ ).

Experiments examined interactions between temperature and Fe availability under 4 conditions: $0^{\circ} \mathrm{C}$ and Fe-limited (+1 $\mathrm{nM} \mathrm{Fe}$; abbreviated $0 \mathrm{C}-\mathrm{Fe}), 0^{\circ} \mathrm{C}$ and Fe-replete (+500 nM Fe; $0 \mathrm{C}+\mathrm{Fe}), 4^{\circ} \mathrm{C}$ and $\mathrm{Fe}-$ limited (+1 nM Fe; $4 \mathrm{C}-\mathrm{Fe}), 4^{\circ} \mathrm{C}$ and Fe-replete (+500 nM Fe; $4 \mathrm{C}+\mathrm{Fe})$. Fe concentration was amended by adding EDTA-chelated $\mathrm{FeCl}_{3}$ (100:1) to $0.2 \mu \mathrm{M}$-filtered trace metal clean Ross Sea seawater. The seawater was collected late in the Antarctic summer, so the concentrations of $\mathrm{NO}_{3}{ }^{-}$and $\mathrm{PO}_{4}{ }^{3-}$ were relatively low for this region at 6.95 and $0.66 \mu \mathrm{mol}^{-1}$, respectively. $\mathrm{Si}(\mathrm{OH})_{4}$ and dissolved Fe concentrations were $52.91 \mathrm{\mu mol} \mathrm{l}^{-1}$ and $0.2 \mathrm{nmol} \mathrm{l}^{-1}$, respectively (Feng et al. 2010). Chaetoceros sp. and one strain of Pseudo-nitzschia subcurvata (P. subcurvata) were grown in this seawater medium without any added nutrients. Another isolate of P. subcurvata, $F$. cylindrus, and $P$. antarctica were maintained under the same 4 conditions, but the seawater was enriched with chelexed nutrient stocks to $50 \mathrm{\mu mol}^{-1} \mathrm{NO}_{3}{ }^{-}$and $10 \mathrm{\mu mol} \mathrm{l}^{-1} \mathrm{PO}_{4}{ }^{3-}$ to examine growth effects of these 2 variables at higher nutrient levels. Cultures grown at high and low major nutrient levels are hereafter identified as HN and LN treatments, respectively.

Experimental cultures were grown in triplicate $500 \mathrm{ml}$ acid-washed polycarbonate bottles under the same light condition as stock cultures. Semi-continuous culturing methods were used, whereby the cultures were diluted every $2 \mathrm{~d}$ with medium preacclimated to their respective temperatures. Dilution rates were based on the individually calculated growth rate of each replicate bottle (see 'Growth rates' section below), allowing each bottle to reach its own steady-state exponential growth rate. All cultures were acclimated to their respective environmental conditions for $8 \mathrm{wk}$ before the commencement of the experiment. After the growth rates remained stable for at least 3 to 5 consecutive transfers (indicating steady-state growth had been attained), the cultures were sampled $48 \mathrm{~h}$ after dilution.

\section{Growth rates}

A $10 \mathrm{ml}$ aliquot of culture samples was taken for visual cell counts directly before and after each treatment was diluted. Cell count samples were preserved with $0.5 \%$ glutaraldehyde (final conc.) and stored at $4^{\circ} \mathrm{C}$ for subsequent counting on a hemocytometer or Sedgwick Rafter Grid using an Olympus BX51 microscope. Due to poor preservation, cell count samples of $P$. antarctica at $4^{\circ} \mathrm{C}$ for phosphorus cell quotas and chlorophyll a (chl a) per cell calculations were lost. Specific growth rates (expressed as $\mathrm{d}^{-1}$ ) were calculated as $\mu=\left(\ln \mathrm{N}_{1}-\ln \mathrm{N}_{0}\right) / t$, where $\mathrm{N}_{0}$ and $\mathrm{N}_{1}$ are the cell densities at the beginning and end of a dilution period, respectively, and $t$ is the duration of the dilution period. $Q_{10}$ for growth rates of all phytoplankton was calculated as $Q_{10}=\left(\mu_{2} / \mu_{1}\right)^{10 /(T 1-T 2)}$ (ChauiBerlinck et al. 2002), where $\mu_{1}$ and $\mu_{2}$ are the specific growth rates of the phytoplankton at temperatures $T_{1}$ $\left({ }^{\circ} \mathrm{C}\right.$ ) and $T_{2}$, respectively.

\section{Elemental and chl $a$ analysis}

Culture samples $(20$ and $50 \mathrm{ml}$ ) from each treatment were filtered onto pre-combusted Whatman GF/F filters $\left(500^{\circ} \mathrm{C}\right.$ for $\left.2 \mathrm{~h}\right)$ and dried in a $60^{\circ} \mathrm{C}$ oven overnight for particulate organic carbon/nitrogen (POC/PON) and particulate organic phosphorus (POP) analyses, respectively. POC/PON samples were analyzed using a 440 Elemental Analyzer (Costech) following Fu et al. (2007) and Garcia et al. (2015). POP was analyzed using a molybdate colorimetric method according to $\mathrm{Fu}$ et al. (2007). A $20 \mathrm{ml}$ aliquot of the Chaetoceros sp. and $P$. subcurvata LN sample from each treatment was filtered onto $2 \mu \mathrm{m}$ polycarbonate filters and dried in a $60^{\circ} \mathrm{C}$ oven overnight for biogenic silica (BSi) analysis (Hutchins et al. 1998).

For chl a analysis, 20 to $50 \mathrm{ml}$ culture samples were filtered onto GF/F filters and extracted with $90 \%$ aqueous acetone for $24 \mathrm{~h}$ at $-20^{\circ} \mathrm{C}$, and measured using the non-acidification method on a 10-AUTM fluorometer (Turner Designs) (Fu et al. 2007). 


\section{Cell volume and surface area}

A minimum of 50 cells (fresh samples for P. antarctica and preserved samples for diatoms) from each treatment were measured using an Olympus BX51 microscope with a coupled Excelis HD camera (ACCU-SCOPE). The length, height, or diameter of all cells were measured using ImageJ (National Institutes of Health), and the volume and surface area of each cell was calculated following Hillebrand et al. (1999).

\section{Active fluorescence characteristics}

A $6 \mathrm{ml}$ aliquot of culture sample of $P$. subcurvata LN and Chaetoceros sp. LN from each treatment was dark-adapted for $15 \mathrm{~min}$, and minimum fluorescence $\left(F_{0}\right)$ was measured using a $10-\mathrm{AU}^{\mathrm{TM}}$ fluorometer. Next, maximum fluorescence $\left(F_{\mathrm{m}}\right)$ was recorded by adding $6 \mu$ lichloromethylurea (DCMU) to each sample followed by shaking for $30 \mathrm{~s}$. The quantum efficiency of photosystem II $\left(F_{\mathrm{v}} / F_{\mathrm{m}}\right)$ was calculated according to the equation $F_{\mathrm{v}} / F_{\mathrm{m}}=\left(F_{\mathrm{m}}-F_{0}\right) / F_{\mathrm{m}}(\mathrm{Kol}-$ ber \& Falkowski 1993).

\section{Carbon fixation and Fe uptake rates}

To measure carbon fixation and Fe uptake rates, a $30 \mathrm{ml}$ aliquot of culture sample from each treatment was incubated with $37 \mathrm{kBq}{ }^{14} \mathrm{C}$-bicarbonate (MP Biomedicals), or $\sim 2 \mathrm{kBq}{ }^{55} \mathrm{FeCl}_{3}$ (PerkinElmer; $0.33 \mathrm{nM}$ ${ }^{55} \mathrm{FeCl}_{3}$ complexed to $120 \mu \mathrm{mol} \mathrm{l}{ }^{-1}$ EDTA) under their respective treatment conditions. Samples were filtered onto GF/F filters after $24 \mathrm{~h}$ incubation. For Fe uptake rate samples, the filters were washed in oxalate reagent for $5 \mathrm{~min}$ followed by a trace metal clean seawater rinse to remove surface-adsorbed Fe (Tovar-Sanchez et al. 2003, Tang \& Morel 2006). To correct for filter absorption of both radiotracers, the same amount of stock solution was added to a $30 \mathrm{ml}$ aliquot of sample and immediately filtered; these filter absorption count values were subtracted from reported activities. The radioactivities of ${ }^{14} \mathrm{C}$ and ${ }^{55} \mathrm{Fe}$ in each sample were counted in a Tri-Carb 2500TR (Packard, now Perkin Elmer). Carbon fixation rates and Fe uptake rates were calculated using the initial dissolved inorganic carbon (DIC) concentrations and initial total Fe concentrations of each bottle (1 nM Fe and $500 \mathrm{nM}$ for Fe-limited and Fe-replete cultures, respectively), and were normalized to cell density (Garcia et al. 2015). Since ${ }^{55} \mathrm{Fe}$ additions were a large fraction of the total Fe present in the Fe-limited samples and were calculated using initial concentrations, these uptake values represent an upper rate estimate for this treatment.

\section{Statistical analysis}

All statistical analyses, including Student's $t$-tests, ANOVA, Tukey's HSD test, and 2-way ANOVA were conducted using the open source statistical software R v.3.1.2 from Systat Software.

\section{RESULTS}

\section{Growth rates and $Q_{10}$ values}

Fe addition significantly increased the growth rates of all phytoplankton tested $(\mathrm{p}<0.05)$ (Fig. 1A, Table S1 in the Supplement at www.int-res.com/ articles/suppl/m550p039_supp.pdf) at both 0 and $4{ }^{\circ} \mathrm{C}$, confirming that Fe-limitation had been successfully achieved for all low-Fe treatments. While the effect of temperature varied between species, the growth rates of both Fe-limited and Fe-replete cultures of Pseudo-nitzschia subcurvata $\mathrm{HN}$ and Fragilariopsis cylindrus HN significantly increased at $4^{\circ} \mathrm{C}(\mathrm{p}<$ 0.05), but only the Fe-replete cultures of $P$. subcurvata LN and Chaetoceros sp. LN were stimulated by the temperature increase $(\mathrm{p}<0.05)$ (Fig. 1A). The $4^{\circ} \mathrm{C}$ temperature increase did not influence the growth rates of the prymnesiophyte Phaeocystis antarctica HN (Fig. 1A). Additionally, the growth rates of P. subcurvata LN and P. subcurvata HN were significantly stimulated by the interactive effects of concurrent temperature and Fe increase; these responses were significantly greater than the additive effects of individual temperature increase and Fe addition ( $\mathrm{p}<$ 0.05). The growth rates of Fe-limited $P$. subcurvata HN significantly increased relative to Fe-limited $P$. subcurvata LN by $63 \%$ at $0^{\circ} \mathrm{C}$ and by $81 \%$ at $4{ }^{\circ} \mathrm{C}$ $(\mathrm{p}<0.05)$, while the growth rates of Fe-replete $P$. subcurvata HN significantly increased by $30 \%$ relative to Fe-replete $P$. subcurvata $\mathrm{LN}$ at $4^{\circ} \mathrm{C}(\mathrm{p}<0.05)$ (Fig. 1A).

The $Q_{10}$ values of Fe-limited $P$. subcurvata LN, P. subcurvata $\mathrm{HN}$, and Chaetoceros sp. LN were approximately 2.0 to 2.8 . The $Q_{10}$ value of Fe-replete $P$. subcurvata LN was 3.07, which was lower than Fereplete $P$. subcurvata $H N$ (4.24) (Fig. 1B). The $Q_{10}$ values of $F$. cylindrus HN (6.56 and 5.06 for Felimited and Fe-replete cultures, respectively) were 

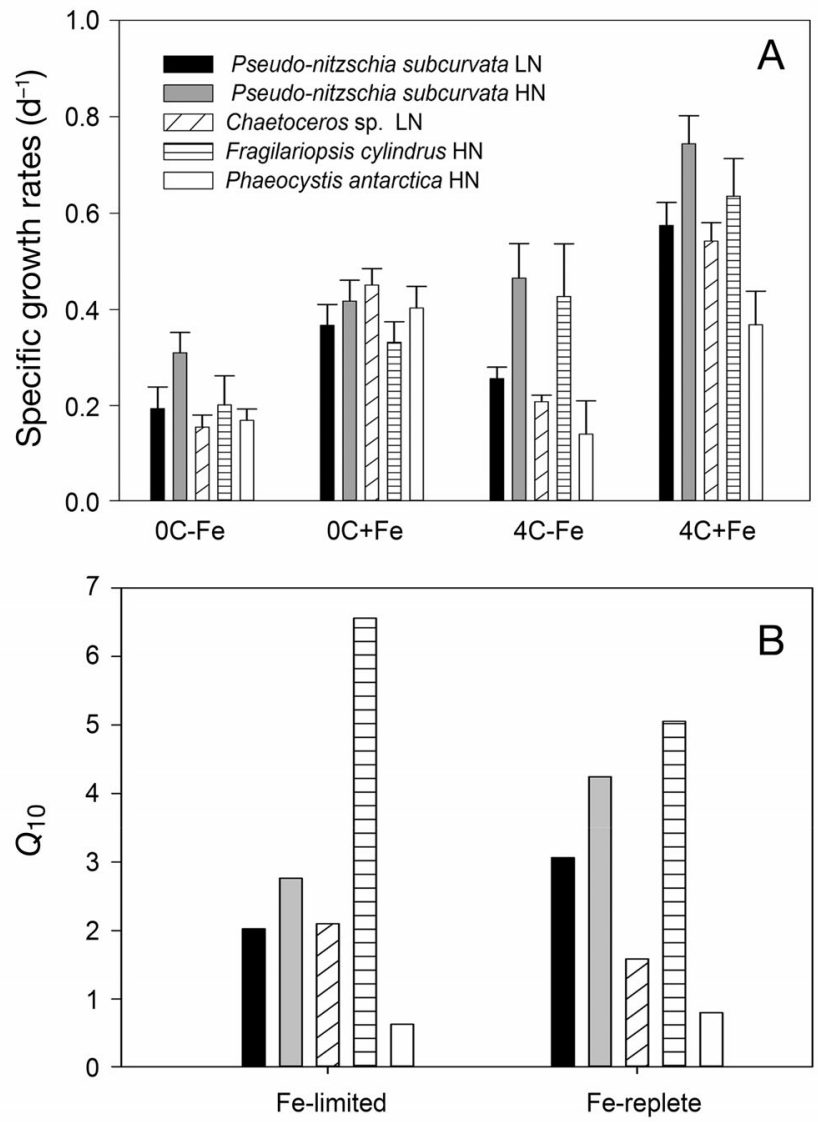

Fig. 1. (A) Specific growth rates and (B) $Q_{10}$ of Pseudonitzschia subcurvata, Pseudo-nitzschia subcurvata, Chaetoceros sp., Fragilariopsis cylindrus, and Phaeocystis antarctica cultures grown in either in high (HN) or low (LN) nutrient levels, at either 0 or $4^{\circ} \mathrm{C}$, under iron-limited $(-\mathrm{Fe})$ or iron-replete $(+\mathrm{Fe})$ conditions

highest amongst all phytoplankton tested (Fig. 1B). In contrast, $Q_{10}$ values of $P$. antarctica HN (0.63 and 0.80 for Fe-limited and Fe-replete cultures, respectively) were much lower than those of all diatoms (Fig. 1B).

\section{Carbon fixation and Fe uptake responses}

The effects of Fe addition on carbon fixation rates were similar to growth rates. Carbon fixation rates of all Fe-replete diatom cultures significantly increased relative to Fe-limited cultures at both 0 and $4{ }^{\circ} \mathrm{C}$ (p < 0.05) (Fig. 2A, Table S1) while the carbon fixation rates of Fe-replete $P$. antarctica HN significantly increased relative to Fe-limited rates only at $0^{\circ} \mathrm{C}(\mathrm{p}<$ 0.05) (Fig. 2A). Temperature increase led to significantly higher carbon fixation rates of Fe-replete $P$. subcurvata HN, F. cylindrus $\mathrm{HN}$, and Chaetoceros sp. LN ( $\mathrm{p}<0.05)$, but significantly decreased the carbon
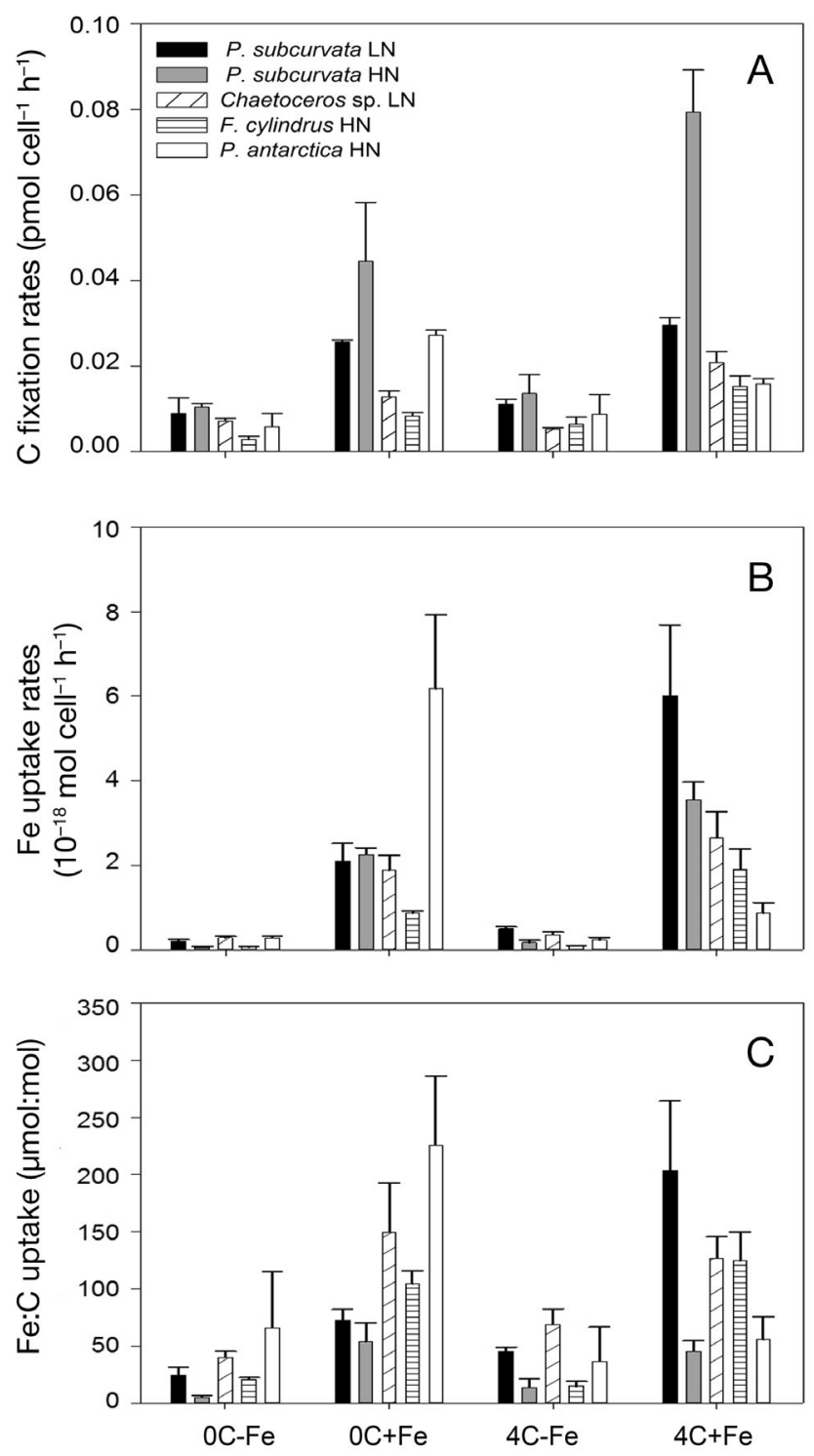

Fig. 2. (A) Carbon fixation rates, (B) iron uptake rates, and (C) Fe:C uptake ratios of Pseudo-nitzschia subcurvata, Chaetoceros sp., Fragilariopsis cylindrus, and Phaeocystis antarctica cultures grown in either in high (HN) or low (LN) nutrient levels, at either 0 or $4^{\circ} \mathrm{C}$, under iron-limited $(-\mathrm{Fe})$ or iron-replete $(+\mathrm{Fe})$ conditions

fixation rates of $P$. antarctica $\mathrm{HN}$ in Fe-replete cultures by $72 \%(\mathrm{p}<0.05)$ (Fig. $2 \mathrm{~A})$. In addition, temperature increase and Fe addition interactively stimulated a 6.6-fold increase in carbon fixation rates of $P$. subcurvata HN and a 1.9-fold increase of Chaetoceros sp. LN ( $\mathrm{p}<0.05)$. The carbon fixation rates of Fe-replete $P$. subcurvata HN significantly increased 1.7-fold relative to $P$. subcurvata $\mathrm{LN}$ at $4^{\circ} \mathrm{C}(\mathrm{p}<0.05)$ (Fig. 2A).

Similar to growth and carbon uptake rates, Fe fertilization significantly increased the Fe uptake rates of all 5 phytoplankton species at both 0 and $4^{\circ} \mathrm{C}(\mathrm{p}<$ 
0.05) (Fig. 2B). Temperature increase significantly elevated the Fe uptake rates of Fe-replete cultures of $P$. subcurvata LN, P. subcurvata HN, and F. cylindrus HN ( $<$ < 0.05) (Fig. 2B). Additionally, temperature increase and Fe fertilization interactively increased the Fe uptake rates of these same 3 strains $(p<0.05)$. The Fe uptake rates of Fe-replete $P$. antarctica HN cultures were significantly decreased by $86 \%$ at $4^{\circ} \mathrm{C}$ relative to $0^{\circ} \mathrm{C}(\mathrm{p}<0.05)$ (Fig. $\left.2 \mathrm{~B}\right)$. The Fe uptake rates of $P$. subcurvata LN were $41 \%$ higher than $P$. subcurvata $\mathrm{HN}$ in $4^{\circ} \mathrm{C}$ Fe-replete cultures $(\mathrm{p}<0.05)$ (Fig. 2B), suggesting that nutrient concentrations may affect Fe uptake rates in this species.

The molar Fe:C uptake ratios of all 4 diatoms were significantly higher with $\mathrm{Fe}$ addition at both 0 and $4^{\circ} \mathrm{C}(\mathrm{p}<0.05)$ (Fig. $\left.2 \mathrm{C}\right)$. Fe addition significantly elevated the Fe:C uptake ratio of $P$. antarctica HN (2.4fold) at $0^{\circ} \mathrm{C}(\mathrm{p}<0.05)$, but not at $4^{\circ} \mathrm{C}$. Furthermore, temperature increase significantly increased the Fe:C uptake ratios of Fe-replete $P$. subcurvata LN by 1.8-fold, and Fe addition and warming interactively affected the $\mathrm{Fe}: \mathrm{C}$ uptake ratio of $P$. antarctica $\mathrm{HN}$ $(\mathrm{p}<0.05)$ (Fig. 2C).
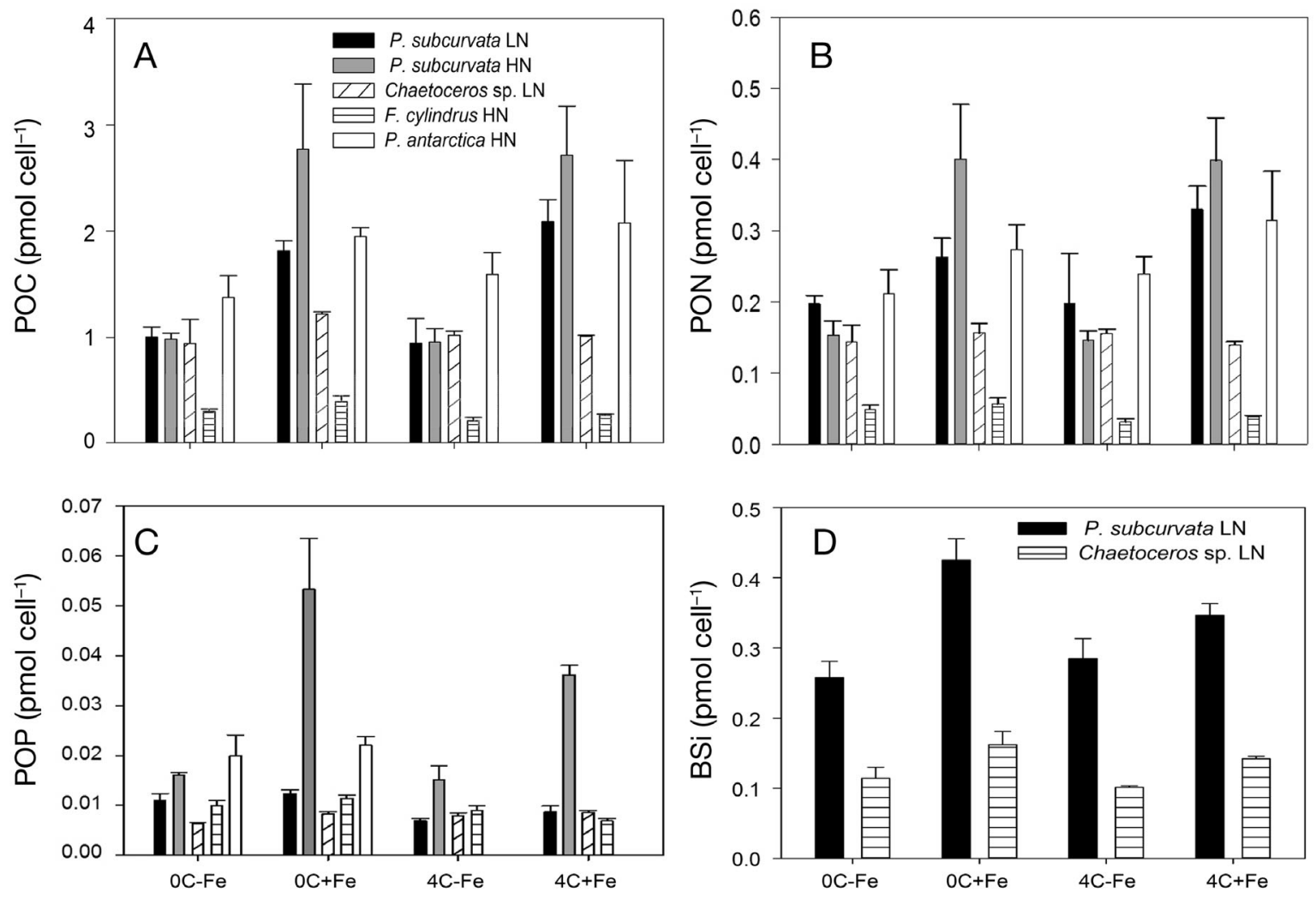

Fig. 3. Particulate organic (A) carbon (POC), (B) nitrogen (PON), and phosphorus (POP), and (D) biogenic silica (BSi) content of Pseudo-nitzschia subcurvata, Chaetoceros sp., Fragilariopsis cylindrus, and Phaeocystis antarctica cultures grown in either in high (HN) or low (LN) nutrient levels, at either 0 or $4^{\circ} \mathrm{C}$, under iron-limited (-Fe) or iron-replete $(+\mathrm{Fe})$ conditions. BSi was measured only for Pseudo-nitzschia subcurvata LN and Chaetoceros sp. LN 
F. cylindrus HN ( $<$ < 0.05) (Fig. 3B). Fe addition significantly increased the phosphorus quota of $P$. subcurvata $\mathrm{HN}$ at 0 and $4^{\circ} \mathrm{C}$, but temperature increase significantly decreased that of Fe-replete $P$. subcurvata $\mathrm{HN}$ by $32 \%$ and Fe-replete $F$. cylindrus $\mathrm{HN}$ by $39 \%(p<0.05)$ (Fig. 3C). Temperature increase significantly decreased the phosphorus quota of both Fe-limited (58\%) and Fe-replete (30\%) P. subcurvata $\mathrm{LN}(\mathrm{p}<0.05)$ (Fig. 3C). Fe addition significantly increased the phosphorus quota of Chaetoceros sp. LN at $0^{\circ} \mathrm{C}(\mathrm{p}<0.05)$, and temperature increase significantly increased the phosphorus quota of Fe-limited Chaetoceros sp. LN ( $<$ 0.05) (Fig. 3C). Fe addition significantly increased the cellular Si quota of $P$. subcurvata LN and Chaetoceros sp. LN at both 0 and $4^{\circ} \mathrm{C}$ $(\mathrm{p}<0.05)$ (Fig. 3D). Temperature increase decreased the Si quota of Fe-replete P. subcurvata LN by $19 \%$ $(\mathrm{p}<0.05)$ (Fig. 3D).

Elemental ratios of the phytoplankton in all experimental treatments are shown in Table 1. Fe addition significantly increased the C:N ratio of $P$. subcurvata LN and Chaetoceros sp. LN at both temperatures ( $\mathrm{p}<$ $0.05)$ and the $\mathrm{C}: \mathrm{N}$ ratio of $F$. cylindrus $\mathrm{HN}$ at $0^{\circ} \mathrm{C}(\mathrm{p}<$ $0.05)$. Temperature increase significantly elevated the C:N ratio of Fe-limited F. cylindrus HN ( $\mathrm{p}<0.05)$ (Table 1). The C:N ratios of Fe-limited P. subcurvata $\mathrm{LN}$ at $0^{\circ} \mathrm{C}$ and $\mathrm{Fe}$-replete $P$. subcurvata $\mathrm{LN}$ at $4^{\circ} \mathrm{C}$ were significantly lower than those of the same species in the HN treatment $(\mathrm{p}<0.05)$ (Table 1$)$.

The N:P ratio of $F$. cylindrus $\mathrm{HN}$ was significantly increased by Fe addition at both 0 and $4^{\circ} \mathrm{C}(\mathrm{p}<0.05)$, as was the N:P ratio of $P$. subcurvata LN at $4^{\circ} \mathrm{C}(\mathrm{p}<$
0.05) (Table 1). In contrast, Fe addition significantly decreased the N:P ratio of $P$. subcurvata $\mathrm{HN}$ and Chaetoceros sp. LN at $4^{\circ} \mathrm{C}(\mathrm{p}<0.05)$ (Table 1). In addition, higher temperature significantly increased the N:P ratio of both Fe-limited and Fe-replete $P$. subcurvata LN $(\mathrm{p}<0.05)$ and the $\mathrm{N}$ :P ratio of Fe-replete $P$. antarctica HN $(\mathrm{p}<0.05)$ (Table 1$)$. The N:P ratios of both Fe-limited and Fe-replete $P$. subcurvata LN at $4^{\circ} \mathrm{C}$ were significantly higher than those of $P$. subcurvata HN ( $\mathrm{p}<0.05)$ (Table 1$)$.

$\mathrm{Fe}$ addition significantly increased the C:P ratio of P. subcurvata LN at both 0 and $4^{\circ} \mathrm{C}(\mathrm{p}<0.05)$, and the C:P ratio of $F$. cylindrus $\mathrm{HN}$ at $4^{\circ} \mathrm{C}(\mathrm{p}<0.05)$ (Table 1). Warmer temperatures significantly increased the C:P ratio of both Fe-limited and Fe-replete P. subcurvata LN ( $\mathrm{p}<0.05)$, and the C:P ratio of Fe-replete $P$. antarctica HN ( $\mathrm{p}<0.05)$ (Table 1). Temperature increase and $\mathrm{Fe}$ addition had no significant effect on the stoichiometry of P. subcurvata HN or Chaetoceros sp. LN (Table 1). However, the C:P ratio of Fereplete $P$. subcurvata $\mathrm{LN}$ at $0^{\circ} \mathrm{C}$ was significantly higher than that of $P$. subcurvata HN $(\mathrm{p}<0.05)$ (Table 1).

\section{Cell morphology}

Fe addition significantly enlarged the cell volume of $P$. subcurvata HN, P. subcurvata LN, and Chaetoceros sp. LN at both temperatures $(\mathrm{p}<0.05)$ (Fig. 4A, Table S1), and cell volume of $F$. cylindrus $\mathrm{HN}$ was significantly enlarged with Fe addition at $4^{\circ} \mathrm{C}(\mathrm{p}<$

Table 1. Effects of temperature and Fe addition on the C:N, N:P, and C:P ratios of Pseudo-nitzschia subcurvata, Chaetoceros sp., Fragilariopsis cylindrus, and Phaeocystis antarctica cultures grown in high (HN) and low (LN) nutrient levels. Values are means \pm SD of triplicate bottles. Different superscript letters indicate significant difference at $\alpha<0.05$

\begin{tabular}{|c|c|c|c|c|c|}
\hline & P. subcurvata LN & P. subcurvata $\mathrm{HN}$ & Chaetoceros sp. LN & F. cylindrus $\mathrm{HN}$ & P. antarctica HN \\
\hline \multicolumn{6}{|l|}{ C:N } \\
\hline $0 \mathrm{C}-\mathrm{Fe}$ & $5.1 \pm 0.5^{\mathrm{a}}$ & $6.5 \pm 0.5^{\mathrm{a}}$ & $6.5 \pm 0.5^{\mathrm{a}}$ & $6.3 \pm 0.3^{\mathrm{a}}$ & $6.5 \pm 0.4^{\mathrm{a}}$ \\
\hline $0 \mathrm{C}+\mathrm{Fe}$ & $6.9 \pm 0.4^{\mathrm{b}}$ & $6.9 \pm 0.2^{\mathrm{a}}$ & $7.9 \pm 0.6^{b}$ & $7.0 \pm 0.0^{\mathrm{b}}$ & $7.2 \pm 0.8^{\mathrm{a}}$ \\
\hline $4 \mathrm{C}-\mathrm{Fe}$ & $4.9 \pm 0.8^{\mathrm{a}}$ & $6.6 \pm 0.3^{\mathrm{a}}$ & $6.6 \pm 0.0^{\mathrm{a}}$ & $7.0 \pm 0.4^{\mathrm{ab}}$ & $6.6 \pm 0.5^{\mathrm{a}}$ \\
\hline $4 \mathrm{C}+\mathrm{Fe}$ & $6.3 \pm 0.2^{\mathrm{b}}$ & $6.8 \pm 0.1^{\mathrm{a}}$ & $7.3 \pm 0.3^{b}$ & $6.9 \pm 0.1^{\mathrm{ab}}$ & $6.6 \pm 0.5^{\mathrm{a}}$ \\
\hline \multicolumn{6}{|l|}{$\mathbf{N}: \mathbf{P}$} \\
\hline $0 \mathrm{C}-\mathrm{Fe}$ & $18.1 \pm 2.7^{\mathrm{a}}$ & $15.3 \pm 0.5^{\mathrm{a}}$ & $23.0 \pm 5.0^{\mathrm{a}}$ & $11.6 \pm 0.6^{\mathrm{a}}$ & $18.5 \pm 3.8^{\mathrm{a}}$ \\
\hline $0 \mathrm{C}+\mathrm{Fe}$ & $21.3 \pm 1.4^{\mathrm{a}}$ & $15.7 \pm 3.7^{\mathrm{abc}}$ & $18.9 \pm 1.6^{\mathrm{ab}}$ & $15.4 \pm 0.8^{\mathrm{b}}$ & $16.7 \pm 0.5^{\mathrm{a}}$ \\
\hline $4 \mathrm{C}-\mathrm{Fe}$ & $28.6 \pm 5.4^{\mathrm{b}}$ & $13.5 \pm 0.4^{\mathrm{b}}$ & $19.6 \pm 0.5^{\mathrm{a}}$ & $11.3 \pm 1.4^{\mathrm{a}}$ & $25.6 \pm 5.2^{\mathrm{a}}$ \\
\hline $4 \mathrm{C}+\mathrm{Fe}$ & $38.1 \pm 1.5^{\mathrm{c}}$ & $12.5 \pm 0.4^{\mathrm{c}}$ & $16.3 \pm 0.3^{b}$ & $15.1 \pm 0.3^{b}$ & $32.5 \pm 2.0^{\mathrm{b}}$ \\
\hline \multicolumn{6}{|l|}{ C:P } \\
\hline $0 \mathrm{C}-\mathrm{Fe}$ & $92.4 \pm 17.9^{\mathrm{a}}$ & $90.6 \pm 6.5^{\mathrm{a}}$ & $151.5 \pm 43.9^{\mathrm{abc}}$ & $75.9 \pm 2.7^{\mathrm{ab}}$ & $134.5 \pm 27.5^{\mathrm{a}}$ \\
\hline $0 \mathrm{C}+\mathrm{Fe}$ & $147.0 \pm 6.4^{\mathrm{b}}$ & $80.1 \pm 17.6^{\mathrm{a}}$ & $147.5 \pm 6.0^{\mathrm{c}}$ & $85.0 \pm 6.7^{\mathrm{a}}$ & $100.4 \pm 5.5^{\mathrm{a}}$ \\
\hline $4 \mathrm{C}-\mathrm{Fe}$ & $136.4 \pm 4.3^{\mathrm{b}}$ & $102.1 \pm 4.5^{\mathrm{a}}$ & $128.4 \pm 3.5^{\mathrm{a}}$ & $63.2 \pm 6.5^{\mathrm{b}}$ & $187.8 \pm 37.7^{\mathrm{a}}$ \\
\hline $4 \mathrm{C}+\mathrm{Fe}$ & $241.6 \pm 13.7^{\mathrm{c}}$ & $80.9 \pm 2.5^{\mathrm{a}}$ & $118.3 \pm 6.8^{\mathrm{b}}$ & $82.0 \pm 3.5^{\mathrm{a}}$ & $214.9 \pm 20.4^{\mathrm{b}}$ \\
\hline
\end{tabular}



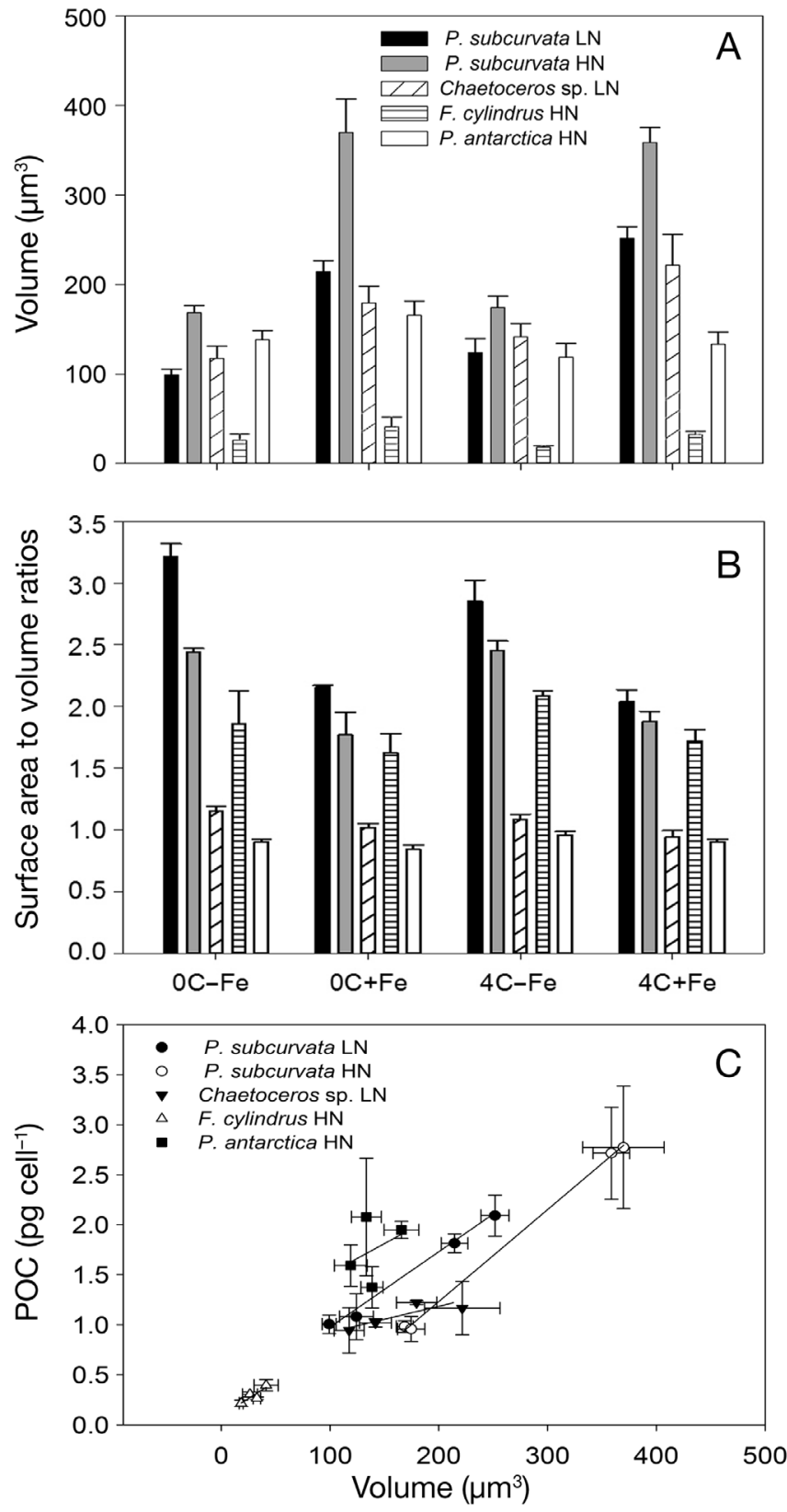

Fig. 4. (A) Cell volume, (B) surface area to cell volume ratios, and (C) relationship of particulate organic carbon (POC) and volume of Pseudo-nitzschia subcurvata, Chaetoceros sp., Fragilariopsis cylindrus, and Phaeocystis antarctica cultures grown in either in high (HN) or low (LN) nutrient levels, at either 0 or $4^{\circ} \mathrm{C}$, under iron-limited $(-\mathrm{Fe})$ or iron-replete $(+\mathrm{Fe})$ conditions

0.05) (Fig. 4A). Warming significantly enlarged the cell volume of Fe-replete $P$. subcurvata LN by $17 \%$ $(p<0.05)$ (Fig. 4A). Corresponding to the effects on cell volume, Fe addition significantly decreased the surface area to volume ratios of $P$. subcurvata $\mathrm{HN}$, P. subcurvata LN, and Chaetoceros sp. LN at both temperatures ( $\mathrm{p}<0.05)$ (Fig. $4 \mathrm{~B})$, but only at $4^{\circ} \mathrm{C}$ for F. cylindrus HN ( $<<0.05)$ (Fig. 4B). Temperature increase diminished the surface area to volume ratio of Fe-replete $P$. subcurvata LN by $5 \%(\mathrm{p}<0.05)$ (Fig. 4B). The cell volume of $P$. subcurvata LN was significantly smaller than $P$. subcurvata $\mathrm{HN}$ in all 4 treatments ( $p<0.05$; Fig. 4A), and the surface area to volume ratio of Fe-limited $P$. subcurvata LN was significantly higher than $P$. subcurvata $\mathrm{HN}$ at both temperatures ( $\mathrm{p}<0.05$; Fig. 4B). Cell volume increased in parallel with carbon quota increases for all 5 strains tested (Fig 4C).

\section{Chl $a$ and photosynthetic characteristics}

The carbon to chl a ratio of Fe-replete Chaetoceros sp. LN and $F$. cylindrus HN significantly decreased relative to Fe-limited cultures at both 0 and $4{ }^{\circ} \mathrm{C}$ ( $\mathrm{p}<$ 0.05) (Fig. 5A, Table S1). In addition, warmer temperature decreased the carbon to $\mathrm{chl}$ a ratio of Fe-limited Chaetoceros sp. LN by $30 \%$ and that of F. cylindrus HN by $49 \%$ (p < 0.05) (Fig. 5A). The amount of chl a cell $^{-1}$ was significantly elevated in Fe-replete cultures of all 4 strains of diatom relative to Fe-limited cultures at both 0 and $4^{\circ} \mathrm{C}(\mathrm{p}<0.05)$ (Fig. 5B). The chl a cell ${ }^{-1}$ of Fe-replete $P$. antarctica HN significantly increased by $50 \%$ relative to Fe-limited cultures at $0^{\circ} \mathrm{C}(\mathrm{p}<0.05)$ (Fig. 5B). Temperature increase significantly decreased the chl a cell ${ }^{-1}$ of Fe-replete $F$. cylindrus $\mathrm{HN}$ by $36 \%$ (p < 0.05) (Fig. 5B). The carbon to chl a ratio of Fe-replete $P$. subcurvata LN was significantly higher than Fe-replete $P$. subcurvata $\mathrm{HN}$ at both 0 and $4^{\circ} \mathrm{C}$, and the carbon to chl a ratio of $\mathrm{Fe}$ limited $P$. subcurvata LN was significantly higher than Fe-limited $P$. subcurvata $\mathrm{HN}$ at $0^{\circ} \mathrm{C}(\mathrm{p}<0.05)$ (Fig. 5A). In addition, the chl a cell ${ }^{-1}$ of Fe-replete $P$. subcurvata LN was significantly lower than Fereplete $P$. subcurvata $\mathrm{HN}$ at both 0 and $4^{\circ} \mathrm{C}$, and the chl a cell ${ }^{-1}$ of Fe-limited $P$. subcurvata LN was significantly smaller than Fe-limited $P$. subcurvata HN at $0^{\circ} \mathrm{C}(\mathrm{p}<0.05)$ (Fig. 5B).

Higher Fe availability significantly increased the $F_{\mathrm{v}} / F_{\mathrm{m}}$ of $P$. subcurvata LN and Chaetoceros sp. LN $(\mathrm{p}<0.05)$ (Fig. 6, Table S1). With Fe addition, $F_{\mathrm{v}} / F_{\mathrm{m}}$ of both $P$. subcurvata LN and Chaetoceros sp. LN increased significantly from $0.18 \pm 0.05$ and $0.15 \pm$ 0.04 to $0.58 \pm 0.03$ and $0.56 \pm 0.01(\mathrm{p}<0.05)$ at $0{ }^{\circ} \mathrm{C}$, respectively; and from $0.22 \pm 0.04$ and $0.19 \pm 0.02$ to $0.49 \pm 0.03$ and $0.50 \pm 0.03(\mathrm{p}<0.05)$ at $4^{\circ} \mathrm{C}$, respectively. The $F_{\mathrm{v}} / F_{\mathrm{m}}$ of both species slightly decreased in response to warming, but this was only significant for P. subcurvata LN ( $\mathrm{p}<0.05)$ (Fig. 6). 

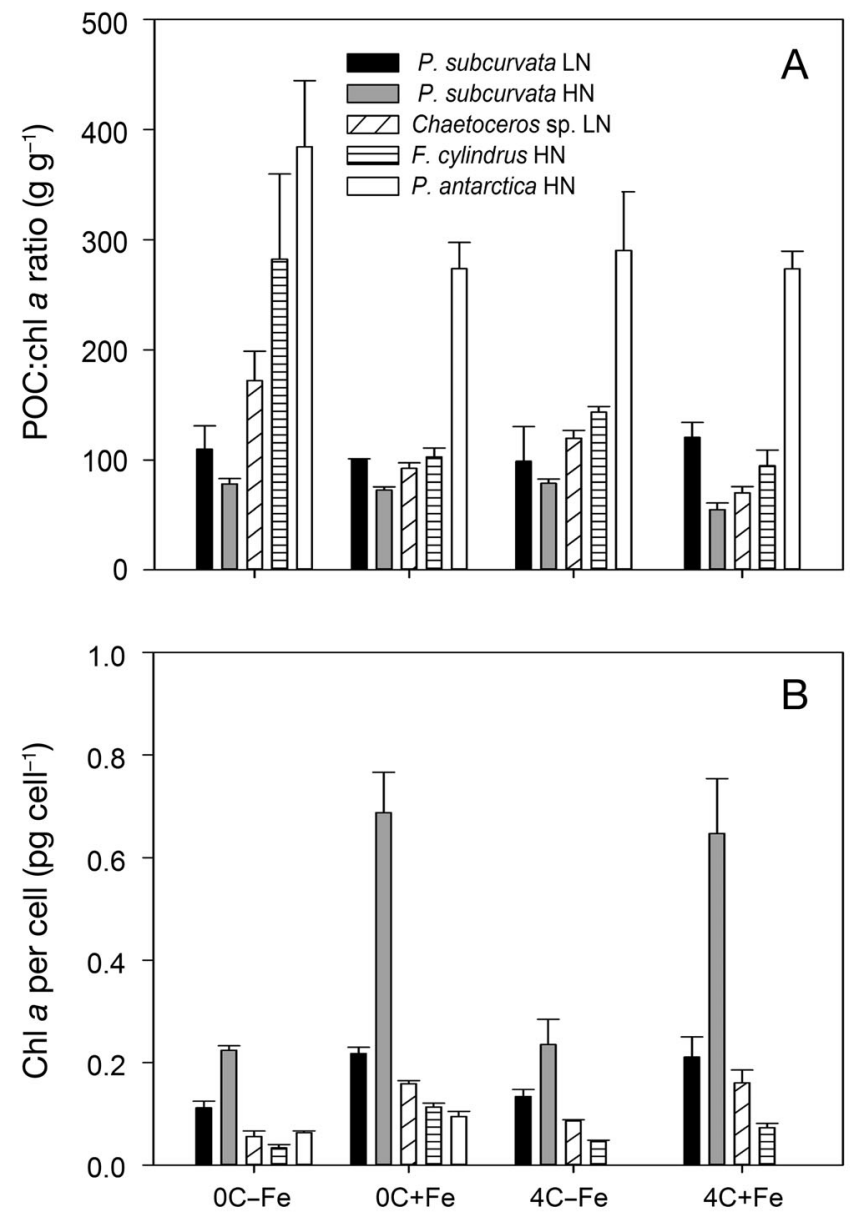

Fig. 5. (A) Particulate organic carbon (POC) to chl a ratio (g $\mathrm{g}^{-1}$ ) and (B) chl a per cell (pg cell ${ }^{-1}$ ) of Pseudo-nitzschia subcurvata, Chaetoceros sp., Fragilariopsis cylindrus, and Phaeocystis antarctica cultures grown in either in high (HN) or low (LN) nutrient levels, at either 0 or $4^{\circ} \mathrm{C}$, under ironlimited $(-\mathrm{Fe})$ or iron-replete $(+\mathrm{Fe})$ conditions



Fig. 6. Quantum efficiency of photosystem II $\left(F_{\mathrm{v}} / F_{\mathrm{m}}\right)$ for Pseudo-nitzschia subcurvata and Chaetoceros sp. cultures grown in low nutrient (LN) levels, at either 0 or $4^{\circ} \mathrm{C}$, under iron-limited $(-\mathrm{Fe})$ or iron-replete $(+\mathrm{Fe})$ conditions

\section{DISCUSSION}

Studies have shown that individual Fe addition or temperature increase can promote the growth of Antarctic phytoplankton (Neori \& Holm-Hansen 1982, Martin et al. 1990, Boyd et al. 2000, Hoffmann et al. 2006); however, the interactive effects of Fe and temperature increase on representative phytoplankton species from the Ross Sea have seldom been reported. In our study, as expected, Fe addition alone significantly promoted the growth rates of all diatoms and of Phaeocystis antarctica HN. However, while higher temperatures also increased the growth rates of Fe-limited and Fe-replete diatoms by 60 and $61 \%$, respectively, it did not significantly affect the growth rate of the prymnesiophyte. The $Q_{10}$ for growth rates of $P$. antarctica $\mathrm{HN}$ ranged from 0.62 to 0.79 , which is lower than 2.0 (the typical $Q_{10}$ value for phytoplankton as suggested by Eppley 1972), and also much lower than the $Q_{10}$ values of the diatom species tested in our study (2.02 to 6.56). This indicates that Ross Sea diatoms may be better adapted to higher temperatures than $P$. antarctica.

The growth rates of $P$. antarctica $\mathrm{HN}\left(0.17 \mathrm{~d}^{-1}\right.$ at $0^{\circ} \mathrm{C}$ and $0.14 \mathrm{~d}^{-1}$ at $4^{\circ} \mathrm{C}$ in Fe-limited cultures, and $0.40 \mathrm{~d}^{-1}$ at $0^{\circ} \mathrm{C}$ and $0.37 \mathrm{~d}^{-1}$ at $4^{\circ} \mathrm{C}$ in Fe-replete cultures) in our study are similar to those observed by Alderkamp et al. (2012). In their study, P. antarctica (strain CCMP1871) was incubated with a $2 \mathrm{~h}$ dynamic light cycle at $2^{\circ} \mathrm{C}$. They observed that the average growth rate was 0.2 and $0.38 \mathrm{~d}^{-1}$ in in Fe-limited and Fe-replete cultures, respectively. Either lack of growth stimulation or decreased growth has also been reported for other cultured $P$. antarctica isolates under higher temperatures. Wang et al. (2010) incubated their strain of $P$. antarctica (CCMP1871) at 0,2 , 4 , and $6^{\circ} \mathrm{C}$, and found that growth rates increased from $0.16 \mathrm{~d}^{-1}$ at $0^{\circ} \mathrm{C}$ to a maximum of $0.35 \mathrm{~d}^{-1}$ at $4^{\circ} \mathrm{C}$, but then sharply decreased to $0.12 \mathrm{~d}^{-1}$ at $6^{\circ} \mathrm{C}$. Xu et al. (2014) incubated $P$. antarctica (CCMP3314) in 3 clustered matrices of environment factors, and found that growth rates were similar $\left(\sim 0.6 \mathrm{~d}^{-1}\right)$ under 'current conditions' $\left(2^{\circ} \mathrm{C}\right.$, $39 \mathrm{~Pa} \mathrm{CO}_{2}$, and $50 \mu \mathrm{mol}$ photons $\mathrm{m}^{-2}$ $\left.\mathrm{s}^{-1}\right)$ and 'year 2060 conditions' $\left(4^{\circ} \mathrm{C}, 61 \mathrm{~Pa} \mathrm{CO}_{2}\right.$, and $100 \mu \mathrm{mol}$ photons $\mathrm{m}^{-2} \mathrm{~s}^{-1}$ ), but significantly decreased to $\sim 0.2 \mathrm{~d}^{-1}$ under simulated 'year 2100 conditions' $\left(6^{\circ} \mathrm{C}, 81 \mathrm{~Pa} \mathrm{CO}_{2}, 150 \mu \mathrm{mol}\right.$ photons $\left.\mathrm{m}^{-2} \mathrm{~s}^{-1}\right)$. The slight differences between maximum growth rates and optimum temperatures in these studies and ours may be due to different strains, and/or different incubation conditions.

There is also a limited amount of research on cultured diatom isolates from the Ross Sea. Alderkamp 
et al. (2012) observed that the growth rates of Fragilariopsis cylindrus (strain CCMP1102) were $0.05 \mathrm{~d}^{-1}$ in Fe-limited and $0.16 \mathrm{~d}^{-1}$ in Fe-replete media at $2^{\circ} \mathrm{C}$. $\mathrm{Xu}$ et al. (2014) found the growth rates of Fe-replete F. cylindrus (CCMP3323) increased from $\sim 0.3 \mathrm{~d}^{-1}$ under 'current conditions' to $\sim 0.6 \mathrm{~d}^{-1}$ in 'year 2060 conditions' (see above), and those of Fe-limited F. cylindrus (CCMP3323) increased from $\sim 0.16 \mathrm{~d}^{-1}$ under 'current conditions' to $\sim 0.22 \mathrm{~d}^{-1}$ in 'year 2060 conditions'. The growth rates of $F$. cylindrus we observed are similar to those reported by Xu et al. (2014), and higher than those of Alderkamp et al. (2012), perhaps because our light cycle differed from that used by Alderkamp et al. (2012).

Carbon fixation and Fe uptake rates of Fe-replete $P$. antarctica $\mathrm{HN}$ both responded to a $4^{\circ} \mathrm{C}$ temperature rise with decreasing trends. Warming-mediated decreases in carbon fixation rates may lead to a reduced demand for $\mathrm{Fe}$ to support synthesis of $\mathrm{chl} a$ and the associated photosystem and electron carrier components. In contrast, like growth and carbon fixation rates, in our Antarctic diatoms Fe uptake rates generally increased with temperature. $\mathrm{Xu}$ et al. (2014) found that the Fe uptake rates of Fe-limited $P$. antarctica (CCMP3314) decreased from the 'current conditions' to the 'year 2100 conditions' clusters, which included warming as well as increasing $\mathrm{CO}_{2}$ concentration and light intensity. However, they found that $\mathrm{Fe}$ uptake rates of Fe-replete $P$. antarctica actually increased slightly under clustered future conditions. The interactive effects of all these environmental factors on Fe uptake rates in P. antarctica and diatoms requires further research.

Our results indicate that Ross Sea diatoms may be better adapted to higher temperatures than $P$. antarctica - which corresponds to Ross Sea field surveys, suggesting that the temporal and spatial distributions of this species are negatively correlated with elevated temperatures (Liu \& Smith 2012). Phytoplankton community dominance shifts caused by experimental warming have also been observed in other high altitude regions. Feng et al. (2009) observed that the dominant algal groups of the North Atlantic spring bloom changed from diatoms to coccolithophores following incubation under high temperature and high $\mathrm{CO}_{2}$ conditions for $14 \mathrm{~d}$. Likewise, in experiments in the subarctic Pacific Noiri et al. (2005) documented that unidentified prymnesiophytes became dominant at $18^{\circ} \mathrm{C}$, while diatoms dominated the phytoplankton community at temperatures below $13^{\circ} \mathrm{C}$. Interestingly, both of these other high latitude studies showed that warming shifted the community towards prymnesiophytes, not away from them as our results suggest for the prymnesiophyte $P$. antarctica.

Fe addition and temperature increase interactively promoted the growth rates of $P$. subcurvata LN and $P$. subcurvata $\mathrm{HN}$ in a synergistic manner; that is, the cumulative effects of $\mathrm{Fe}$ addition and temperature increase far exceeded the magnitude of the additive effects of these 2 factors. Rose et al. (2009) documented synergistic effects of temperature increase and Fe addition on total phytoplankton biomass and on the abundance of specific groups (including diatoms and nanoplankton) in a Ross Sea shipboard experiment. In addition, temperature increase in combination with Fe addition in the Rose et al. (2009) study shifted diatom community structure towards the centric Chaetoceros sp., and away from pennate diatoms. Such a shift would not be predicted by the results of our laboratory culture study, in which both a centric diatom (Chaetoceros) and a pennate diatom (Pseudo-nitzschia) benefited from a synergistic interaction between Fe and warming. In multifactor (temperature, light, $\mathrm{CO}_{2}$, and $\mathrm{Fe}$ ) cluster competition experiments between $F$. cylindrus and $P$. antarctica, $\mathrm{Xu}$ et al. (2014) showed that the diatom outcompeted $P$. antarctica under simulated future conditions.

The effects of temperature increase and changes in Fe input on phytoplankton community succession and species composition may also affect the biogeochemical cycle of carbon and nitrogen in the Southern Ocean (DiTullio et al. 2000, Smetacek et al. 2012). $P$. antarctica has higher $\mathrm{C}: \mathrm{N}$ and $\mathrm{C}: \mathrm{P}$ ratios than diatoms (Arrigo et al. 1999, Xu et al. 2014). Indeed, our results indicate that the N:P ratio of Fe-replete $P$. antarctica HN was higher than Fe-replete $P$. subcurvata $\mathrm{HN}$ and $\mathrm{Fe}$-replete $F$. cylindrus $\mathrm{HN}$ at $4^{\circ} \mathrm{C}$, and the $\mathrm{N}: \mathrm{P}$ ratio of $\mathrm{Fe}$-limited $P$. antarctica $\mathrm{HN}$ was higher than Fe-limited $F$. cylindrus $\mathrm{HN}$ at $4^{\circ} \mathrm{C}(\mathrm{p}<$ 0.05) (Table 1). In addition, the C:P ratios of Fereplete $P$. antarctica $\mathrm{HN}$ were higher than Fe-replete $P$. subcurvata $\mathrm{HN}$ at $4^{\circ} \mathrm{C}$ and Fe-replete F. cylindrus $\mathrm{HN}$ at both temperatures, and the $\mathrm{C}: \mathrm{P}$ ratio of $\mathrm{Fe}-$ limited $P$. antarctica HN was higher than that of Felimited F. cylindrus $\mathrm{HN}$ at $4^{\circ} \mathrm{C}(\mathrm{p}<0.05)$ (Table 1). Thus, if warming or interactions between changing Fe and temperature conditions cause shifts away from $P$. antarctica and towards diatoms, carbon export per mole of phosphorus utilized and the N:P ratio of exported organic matter may also decrease in the future Ross Sea (Arrigo et al. 1999, DiTullio et al. 2000, Smetacek et al. 2012).

Our results suggest that decreasing cell sizes and consequent increases in surface area to cell volume quotients is a common response to Fe limitation by 
Ross Sea phytoplankton. The cell size of all the diatoms and $P$. antarctica decreased in Fe-limited culture relative to Fe-replete cultures. This was particularly evident for $P$. subcurvata grown at both nutrient levels; for this species, cell size decreased by half in Fe-limited cultures. Increased surface area to cell volume quotients may facilitate Fe uptake under Felimited conditions (Sunda \& Huntsman 1997, Sunda \& Hardison 2010). Decreased cell size also means that less $\mathrm{Fe}$, carbon, and nutrients has to be accumulated before cell division can occur, allowing the maintenance of higher cell-specific growth rates (Garcia et al. 2015). Decreases in cell size under Fe limitation have been recorded in marine cyanobacteria, diatoms, and dinoflagellates, suggesting that this is a common response to a lack of this essential micronutrient (Sunda \& Huntsman 1997, Hutchins et al. 1998, Timmermans et al. 2001, Garcia et al. 2015).

Our results indicate that $\mathrm{Fe}$ addition increased the efficiency of photosystem II in P. subcurvata LN and Chaetoceros sp. LN at both 0 and $4^{\circ} \mathrm{C}$, consistent with many studies in the Southern Ocean, including mesoscale Fe-enrichment and shipboard incubation experiments (Boyd et al. 2000, Coale et al. 2004, Rose et al. 2009). Since $F_{\mathrm{v}} / F_{\mathrm{m}}$ measures electron transfer efficiency rather than enzyme-based biochemical reactions, it is usually assumed to be relatively insensitive to temperature. In our experiments, $P$. subcurvata LN exhibited a small but significant decrease in $F_{\mathrm{v}} / F_{\mathrm{m}}$ under Fe-replete conditions with increasing temperature. Negative effects of temperature increase on photosystem II electron flow have occasionally been reported in other phytoplankton and plants (Warner et al. 1996, Geel et al. 1997, Zobayed et al. 2005), but the reason for this warming effect is unclear.

Our results also suggest that $P$. subcurvata may have the potential to become Fe- and nutrient co-limited at the end of the austral summer under future conditions, especially in nearshore areas such as McMurdo Sound where nutrients are often largely drawn down by the end of the growing season. The growth rates of Fe-limited $P$. subcurvata LN were lower than those of Fe-limited $P$. subcurvata $\mathrm{HN}$ at both experimental temperatures, and the growth rates of Fe-replete $P$. subcurvata LN were lower than those of replete $\mathrm{HN}$ cultures at $4^{\circ} \mathrm{C}$. Furthermore, in both the Fe-limited and Fe-replete warmed treatments, the C:P ratio of $P$. subcurvata LN was higher than that of $P$. subcurvata $\mathrm{HN}$, and higher than the Redfield ratio (Falkowski 2000, Geider \& LaRoche 2002). The C:P ratio of Fe-replete $P$. subcurvata LN was also significantly higher than that of the HN treatment and the Redfield ratio at $0^{\circ} \mathrm{C}$. In addition, the cell size and phosphorus quota of P. subcurvata LN were significantly smaller than $P$. subcurvata HN in all 4 treatments. Smaller cell size (and thus lower cellular nutrient quotas) may be a potential strategy for $P$. subcurvata to maintain a competitive advantage during periods of lower seasonal nutrient availability, as seen in some phytoplankton from other environments (Garcia et al. 2015). We did not test our other 3 isolates (Chaetoceros, Fragilariopsis, and Phaeocystis) under both nutrient conditions. However, future investigations may find that there are significant Fe and major nutrient co-limitation effects for them as well, interactions that could be important in coastal portions of the Southern Ocean where nutrients can be seasonally drawn down to relatively low levels.

Our results may support suggestions that global warming and potential changes in Fe supplies may alter phytoplankton community structure in the future Ross Sea. In general, our study suggests that warming, either with or without concurrent Fe fertilization, may cause the spatial and temporal distributions of diatoms to expand while the distribution of $P$. antarctica may shrink. It is important to consider, however, that the competitive balance between diatoms and $P$. antarctica will also likely be affected by other factors that are changing along with global warming, such as ocean acidification, irradiance and salinity changes, shifts in the grazing community (Boyd \& Hutchins 2012), and the availability of other micronutrients and organic cofactors such as vitamins to the phytoplankton community in the coastal Southern Ocean (Bertrand et al. 2015). Additionally, the responses of diatoms and $P$. antarctica to a wider temperature range will be important to determine, as response curves that include a range of temperatures may provide deeper insights into the competitive interplay between these 2 groups of phytoplankton in a rapidly changing Southern Ocean.

Acknowledgements. This work was supported by National Science Foundation grants ANT 1043748 to D.A.H. and 1043635 to D.A.B. We thank Avery Tatters for isolating the strains.

\section{LITERATURE CITED}

Ainley DG, Russell J, Jenouvrier S, Woehler E, Lyver POB, Fraser WR, Kooyman GL (2010) Antarctic penguin response to habitat change as Earth's troposphere reaches $2{ }^{\circ} \mathrm{C}$ above pre-industrial levels. Ecol Monogr 80:49-66

Alderkamp AC, Kulk G, Buma AG, Visser RJ, Van Dijken GL, Mills MM, Arrigo KR (2012) The effect of iron limitation on the photophysiology of Phaeocystis antarctica (Prymnesio- 
phyceae) and Fragilariopsis cylindrus (Bacillariophyceae) under dynamic irradiance. J Phycol 48:45-59

Anderson RF, Ali S, Bradtmiller LI, Nielsen SHH, Fleisher MQ, Anderson BE, Burckle LH (2009) Wind-driven upwelling in the Southern Ocean and the deglacial rise in atmospheric $\mathrm{CO}_{2}$. Science 323:1443-1448

Arrigo KR, Worthen DL, Schnell A, Lizotte MP (1998) Primary production in Southern Ocean waters. J Geophys Res 103:15587-15600

Arrigo KR, Robinson DH, Worthen DL, Dunbar RB, DiTullio GR, Van Woert M, Lizotte MP (1999) Phytoplankton community structure and the drawdown of nutrients and $\mathrm{CO}_{2}$ in the Southern Ocean. Science 283:365-367

Arrigo KR, DiTullio GR, Dunbar RB, Robinson DH, Van Woert M, Worthen DL, Lizotte MP (2000) Phytoplankton taxonomic variability in nutrient utilization and primary production in the Ross Sea. J Geophys Res 105: 8827-8846

Arrigo KR, Van Dijken, GL, Bushinsky S (2008a) Primary production in the Southern Ocean, 1997-2006. J Geophys Res 113:C08004, doi:10.1029/2007JC004551

Arrigo KR, Van Dijken G, Long M (2008b) Coastal Southern Ocean: a strong anthropogenic $\mathrm{CO}_{2}$ sink. Geophys Res Lett 35:L21602, doi:10.1029/2008GL035624

Bertrand EM, McCrow JP, Zheng H, Moustafa A and others (2015) Phytoplankton-bacterial interactions mediate micronutrient colimitation at the coastal Antarctic sea ice edge. Proc Natl Acad Sci USA 112:9938-9943

Boyd PW, Doney SC (2002) Modelling regional responses by marine pelagic ecosystems to global climate change. Geophys Res Lett 29:53-56

> Boyd PW, Hutchins DA (2012) Understanding the responses of ocean biota to a complex matrix of cumulative anthropogenic change. Mar Ecol Prog Ser 470:125-135

Boyd PW, Watson AJ, Law CS, Abraham ER and others (2000) A mesoscale phytoplankton bloom in the polar Southern Ocean stimulated by iron fertilization. Nature 407:695-702

Caron DA, Dennett MR, Lonsdale DJ, Moran DM, Shalapyonok L (2000) Microzooplankton herbivory in the Ross Sea, Antarctica. Deep-Sea Res II 47:3249-3272

Chaui-Berlinck JG, Monteiro LHA, Navas CA, Bicudo JEP (2002) Temperature effects on energy metabolism: a dynamic system analysis. Proc R Soc B 269:15-19

Coale KH, Johnson KS, Chavez FP, Buesseler KO and others (2004) Southern Ocean iron enrichment experiment: carbon cycling in high- and low-Si waters. Science 304: 408-414

> Comiso JC, Kwok R, Martin S, Gordon AL (2011) Variability and trends in sea ice extent and ice production in the Ross Sea. J Geophys Res 116:C04021, doi:101029/2010 JC006391

Cook AJ, Fox AJ, Vaughan DG, Ferrigno JG (2005) Retreating glacier fronts on the Antarctic Peninsula over the past half-century. Science 308:541-544

de Baar H, Buma A, Nolting RF, Cadee GC, Jacques G, Treguer PJ (1990) On iron limitation of the Southern Ocean: experimental observations in the Weddell and Scotia Seas. Mar Ecol Prog Ser 65:105-122

DiTullio GR, Smith WO (1996) Spatial patterns in phytoplankton biomass and pigment distributions in the Ross Sea. J Geophys Res 101:18467-18477

> DiTullio GR, Grebmeier JM, Arrigo KR, Lizotte MP and others (2000) Rapid and early export of Phaeocystis antarctica blooms in the Ross Sea, Antarctica. Nature 404: 595-598

Elrod VA, Berelson WM, Coale KH, Johnson KS (2004) The flux of iron from continental shelf sediments: a missing source for global budgets. Geophys Res Lett 31:L12307, doi:10.1029/2004GL020216

Eppley RW (1972) Temperature and phytoplankton growth in the sea. Fish Bull 70:1063-1085

> Falkowski PG (2000) Rationalizing elemental ratios in unicellular algae. J Phycol 36:3-6

Feng Y, Hare CE, Leblanc K, Rose JM and others (2009) The effects of increased $p \mathrm{CO}_{2}$ and temperature on the North Atlantic spring bloom. I. The phytoplankton community and biogeochemical response. Mar Ecol Prog Ser 388: 13-25

Feng Y, Hare CE, Rose JM, Handy SM and others (2010) Interactive effects of iron, irradiance and $\mathrm{CO}_{2}$ on Ross Sea phytoplankton. Deep-Sea Res I 57:368-383

> Fu FX, Warner ME, Zhang Y, Feng Y, Hutchins DA (2007) Effects of increased temperature and $\mathrm{CO}_{2}$ on photosynthesis, growth and elemental ratios of marine Synechococcus and Prochlorococcus (Cyanobacteria). J Phycol 43:485-496

Garcia NS, Fu F, Sedwick PN, Hutchins DA (2015) Iron deficiency increases growth and nitrogen-fixation rates of phosphorus-deficient marine cyanobacteria. ISME J 9: 238-245

Geel C, Versluis W, Snel JF (1997) Estimation of oxygen evolution by marine phytoplankton from measurement of the efficiency of Photosystem II electron flow. Photosynth Res 51:61-70

Geider R, La Roche J (2002) Redfield revisited: variability of $\mathrm{C}: \mathrm{N}: \mathrm{P}$ in marine microalgae and its biochemical basis. Eur J Phycol 37:1-17

Goffart A, Catalano G, Hecq JH (2000) Factors controlling the distribution of diatoms and Phaeocystis in the Ross Sea. J Mar Syst 27:161-175

- Hare CE, DiTullio GR, Riseman SF, Crossley AC, Popels LC, Sedwick PN, Hutchins DA (2007) Effects of changing continuous iron input rates on a Southern Ocean algal assemblage. Deep-Sea Res I 54:732-746

Hillebrand H, Dürselen CD, Kirschtel D, Pollingher U, Zohary $\mathrm{T}$ (1999) Biovolume calculation for pelagic and benthic microalgae. J Phycol 35:403-424

- Hoffmann LJ, Peeken I, Lochte K, Assmy P, Veldhuis M (2006) Different reactions of Southern Ocean phytoplankton size classes to iron fertilization. Limnol Oceanogr 51: 1217-1229

Hutchins DA, DiTullio GR, Zhang Y, Bruland KW (1998) An iron limitation mosaic in the California coastal upwelling regime. Limnol Oceanogr 43:1037-1054

Hutchins DA, Sedwick PN, DiTullio GR, Boyd PW, Griffiths FB, Queguiner B, Crossley AC (2002) Control of phytoplankton growth by iron and silicic acid availability in the subantarctic Southern Ocean: experimental results from the SAZ project. J Geophys Res 106:559-572

Jickells TD, An ZS, Andersen KK, Baker AR and others (2005) Global iron connections between desert dust, ocean biogeochemistry, and climate. Science 308:67-71

King AL, Sañudo-Wilhelmy SA, Boyd PW, Twining BS and others (2012) A comparison of biogenic iron quotas during a diatom spring bloom using multiple approaches. Biogeosciences 9:667-687

Knox GA (1994) The biology of the Southern Ocean. Cambridge University Press, New York, NY

Kolber Z, Falkowski PG (1993) Use of active fluorescence to estimate phytoplankton photosynthesis in situ. Limnol Oceanogr 38:1646-1665

Leventer A, Dunbar RB (1996) Factors influencing the distribution of diatoms and other algae in the Ross Sea. J Geo- 
phys Res 101:18489-18500

Liu X, Smith WO (2012) Physiochemical controls on phytoplankton distribution in the Ross Sea, Antarctica. J Mar Syst 94:135-144

Mahowald NM, Luo C (2003) A less dusty future? Geophys Res Lett 30:1903, doi:10.1029/2003GL017880

$>$ Manabe S, Stouffer RJ (1993) Century-scale effects of increased atmospheric $\mathrm{CO}_{2}$ on the ocean-atmosphere system. Nature 364:215-218

Martin JH, Fitzwater SE, Gordon RM (1990) Iron deficiency limits phytoplankton growth in Antarctic waters. Global Biogeochem Cycles 4:5-12

Montes-Hugo M, Doney SC, Ducklow HW, Fraser W, Martinson D, Stammerjohn SE, Schofield O (2009) Recent changes in phytoplankton communities associated with rapid regional climate change along the western Antarctic Peninsula. Science 323:1470-1473

> Neori A, Holm-Hansen O (1982) Effect of temperature on rate of photosynthesis in Antarctic phytoplankton. Polar Biol 1:33-38

Noiri Y, Kudo I, Kiyosawa H, Nishioka J, Tsuda A (2005) Influence of iron and temperature on growth, nutrient utilization ratios and phytoplankton species composition in the western subarctic Pacific Ocean during the SEEDS experiment. Prog Oceanogr 64:149-166

Overpeck JT, Otto-Bliesner BL, Miller GH, Muhs DR, Alley RB, Kiehl JT (2006) Paleoclimatic evidence for future icesheet instability and rapid sea-level rise. Science 311: 1747-1750

Raiswell R, Tranter M, Benning LG, Siegert M, De'ath R, Huybrechts P, Payne T (2006) Contributions from glacially derived sediment to the global iron (oxyhydr) oxide cycle: implications for iron delivery to the oceans. Geochim Cosmochim Acta 70:2765-2780

Raiswell R, Benning LG, Tranter M, Tulaczyk S (2008) Bioavailable iron in the Southern Ocean: the significance of the iceberg conveyor belt. Geochem Trans 9:art7

Rose JM, Feng Y, DiTullio GR, Dunbar RB and others (2009) Synergistic effects of iron and temperature on Antarctic phytoplankton and microzooplankton assemblages. Biogeosciences 6:3131-3147

Sarmiento JL, Hughes TM, Stouffer RJ, Manabe S (1998) Simulated response of the ocean carbon cycle to anthropogenic climate warming. Nature 393:245-249

Schoemann V, Becquevort S, Stefels J, Rousseau V, Lancelot C (2005) Phaeocystis blooms in the global ocean and their controlling mechanisms: a review. J Sea Res 53: 43-66

Sedwick PN, DiTullio GR (1997) Regulation of algal blooms in Antarctic shelf waters by the release of iron from melting sea ice. Geophys Res Lett 24:2515-2518

Sedwick PN, DiTullio GR, Mackey DJ (2000) Iron and manganese in the Ross Sea, Antarctica: seasonal iron limitation in Antarctic shelf waters. J Geophys Res 105: 11321-11336

Smetacek V, Klaas C, Strass VH, Assmy P and others (2012) Deep carbon export from a Southern Ocean iron-fertilized diatom bloom. Nature 487:313-319

Editorial responsibility: Ronald Kiene,

Mobile, Alabama, USA
Smith WO, Marra J, Hiscock MR, Barber RT (2000) The seasonal cycle of phytoplankton biomass and primary productivity in the Ross Sea, Antarctica. Deep-Sea Res II 47: 3119-3140

Smith WO, Sedwick PN, Arrigo KR, Ainley DG, Orsi AH (2012) The Ross Sea in a sea of change. Oceanography (Wash DC) 25:90-103

Stammerjohn S, Massom R, Rind D, Martinson D (2012) Regions of rapid sea ice change: an inter-hemispheric seasonal comparison. Geophys Res Lett 39:L06501, doi: 10.1029/2012GL050874

Sunda WG, Hardison DR (2010) Evolutionary tradeoffs among nutrient acquisition, cell size, and grazing defense in marine phytoplankton promote ecosystem stability. Mar Ecol Prog Ser 401:63-76

> Sunda WG, Huntsman SA (1997) Interrelated influence of iron, light and cell size on marine phytoplankton growth. Nature 390:389-392

Takeda S (1998) Influence of iron availability on nutrient consumption ratio of diatoms in oceanic waters. Nature 393:774-777

Tang D, Morel FM (2006) Distinguishing between cellular and Fe-oxide-associated trace elements in phytoplankton. Mar Chem 98:18-30

- Tegen I, Werner M, Harrison SP, Kohfeld KE (2004) Relative importance of climate and land use in determining present and future global soil dust emission. Geophys Res Lett 31:L05105, doi:10.1029/2003GL019216

> Timmermans KR, Davey MS, Van der Wagt B, Snoek J and others (2001) Co-limitation by iron and light of Chaetoceros brevis, C. dichaeta and C. calcitrans (Bacillariophyceae). Mar Ecol Prog Ser 217:287-297

Tovar-Sanchez A, Sañudo-Wilhelmy SA, Garcia-Vargas M, Weaver RS, Popels LC and others (2003). A trace metal clean reagent to remove surface-bound iron from marine phytoplankton. Mar Chem 82:91-99

Tréguer P, Nelson DM, Van Bennekom AJ, Demaster DJ, Leynaert A, Quéguiner B (1995) The silica balance in the world ocean: a reestimate. Science 268:375-379

- Vaughan DG, Marshall GJ, Connolley WM, Parkinson C and others (2003) Recent rapid regional climate warming on the Antarctic Peninsula. Clim Change 60:243-274

> Wang X, Tang KW, Wang Y, Smith WO (2010) Temperature effects on growth, colony development and carbon partitioning in three Phaeocystis species. Aquat Biol 9: 239-249

> Warner ME, Fitt WK, Schmidt GW (1996) The effects of elevated temperature on the photosynthetic efficiency of zooxanthellae in hospite from four different species of reef coral: a novel approach. Plant Cell Environ 19:291-299

> Xu K, Fu FX, Hutchins DA (2014) Comparative responses of two dominant Antarctic phytoplankton taxa to interactions between ocean acidification, warming, irradiance, and iron availability. Limnol Oceanogr 59:1919-1931

Zobayed SMA, Afreen F, Kozai T (2005) Temperature stress can alter the photosynthetic efficiency and secondary metabolite concentrations in St. John's wort. Plant Physiol Biochem 43:977-984

Submitted: November 16, 2015; Accepted: April 11, 2016

Proofs received from author(s): May 19, 2016 